\title{
COGNITIVE LINGUISTICS AND THE LAW
}

JAVIER VALENZUELA MANZANARES

Universidad de Murcia

jvalen@um.es

\section{ABSTRACT}

Cognitive Linguistics (CL) believes that the study of language can be informative with regards to human thought processes. If language is built on top of more basic, non-linguistic cognitive skills, then some of the mechanisms behind language must surely also be used in other areas of cognition. This means that some of the explanations proposed by CL could help us clarify aspects of human behavior that go well beyond language. The present work is an attempt at looking at a number of mechanisms used in CL to explain language, and see how they shed light on one specific human area: that of our current legal system. The claim is that the processes that constitute our legal systems can be seen from a fresh perspective and can probably be better understood using some of the insights of cognitive linguistics. We will focus preferentially on mechanisms such as categorization processes, the windowing of attention, and framing strategies, including the use of metaphors.

KEYWORDS: categorization; metaphor; windowing of attention; framing; metaphoric framing; legal systems.

\section{LINGÜÍSTICA COGNITIVA Y LA LEY}

\section{RESUMEN}

La Lingüística Cognitiva (LC) sostiene que el estudio del lenguaje puede ofrecernos información sobre algunos de los procesos cognitivos humanos. Si el lenguaje está construido sobre capacidades no lingüísticas más básicas, entonces algunos de los mecanismos que subyacen al lenguaje deben con toda probabilidad ser utilizados en otras áreas de la cognición. Esto quiere decir que la LC podría ayudarnos a clarificar aspectos del comportamiento humano que van más allá del lenguaje. El presente trabajo es un intento de examinar algunos de los mecanismos utilizados en la LC para explicar los procesos lingüísticos y ver hasta qué punto son útiles para iluminar un área específica de la actividad humana: nuestro sistema legal. La afirmación es que los procesos que constituyen nuestros sistemas legales pueden ser vistos desde una perspectiva novedosa y probablemente pueden ser entendidos de manera más integradora, utilizando algunas de las explicaciones utilizadas en LC. Nos centraremos de manera especial en mecanismos como los procesos de categorización, la focalización de la atención y las estrategias de enmarcado (framing), incluyendo las estrategias basadas en la conceptualización metafórica

PALABRAS CLAVE: categorización; metáfora; vocalización de la atención; enmarcado; enmarcado metafórico; sistemas legales.

\section{INTRODUCTION}

Cognitive Linguistics (henceforth, CL) deems language not as an autonomous, independent facet of cognition but, rather, as inextricably related to other mental processes such as categorization, perception, memory, attention or emotion, to name a few. That is why CL thinks that a close examination of the 
mechanisms that explain language can help us unveil some of the strategies we use in other areas of cognition. Therefore, it is possible that some of the explanations proposed by CL can be effectively employed to elucidate facets of human behavior that go well beyond language. This paper will look at a number of mechanisms used in CL to explain language and see how they shed light on one specific human area: that of our current legal system. The claim is that the processes that lie at the center of our legal systems can be seen from a fresh perspective and can probably be better understood using some of the mechanisms used in CL.

It is not our intention to provide a complete and thorough account of the whole English legal system. Legal systems are exceedingly complex and have multiple realms of application that depend on the specific area involved and the viewpoint taken: constitutional law, administrative law, criminal law, financial law, fiscal law, international public law, etc. These different subsystems also interact in complex, layered ways, requiring the careful thought of specialists to resolve specific issues. Nonetheless, there is a common abstract structure which underlies all types of legal practices: the most important action in the application of the law is to take a given action or event and classify it in relation to one of several pre-specified cases. This process is in fact an act of "categorization", an area thoroughly studied by CL. Since this is the most basic event in the whole legal chain, and categorization is such a complex issue (as we shall see in Section 3), there are normally three agents involved: the first one is the person actually making the decision on how to classify a given case (the "judge"). Then there are two other agents, called the "prosecutor" and the "defense attorney"1 that argue against each other to try and influence the categorization of a given case towards one direction or another. The strategies that lawyers follow in their attempt to sway the categorization process in one given direction typically involve devices carefully studied in CL, which are known as "framing" (Section 4). A very specific and common framing strategy is the use of "metaphor"; this will be the focus of Section 5. This categorization process is actually embedded in an overarching metaphoric system, since moral actions are typically conceptualized metaphorically. Our present legal system can be said to be based on one concrete metaphor, the "accountancy" metaphor, by which moral actions are given a concrete value and people have to "pay the price" depending on how a certain action is graded according to the system. We start by examining these morality metaphors in Section 2.

\footnotetext{
1 These are intended as generic names; the specific labels of the persons adopting these roles can vary depending according to the different legal systems.

2 This connection, which is posited by supporters of "natural law", is not as straightforward as could be initially thought. Defenders of "positive law" opt instead for a separation of legal codes from natural law. However, this is a more technical argument, and the connections between law and morality seem clear enough to lay people.

${ }^{3}$ Cognitive science has made some progress into this problem. Apparently, the
} 


\section{MORALITY METAPHORS: HOW WE CONCEPTUALIZE MORALITY}

The connections between law and morality are quite transparent, and have been posited by many theorists such as Plato, Aristotle, St. Thomas Aquinas, Thomas Hobbes and John Locke, to cite a few. These connections are also present in the different "Bills of Rights" which are applied internationally. ${ }^{2}$ A basic sense of morality is in all probability innate in humans (De Waal 2009, Hauser 2006), since it is also present in some primates. For example, it has been shown that capuchin monkeys will reject a reward as a protest when they see other monkeys receiving greater rewards than them, revealing a basic sense of injustice or unfairness (Brosnan and De Waal 2003). However, our current sense of morality involves quite complex mental machinery, including a sophisticated theory of mind capacities (Baird and Astington 2004). MORALITY is by definition an abstract domain, not directly related to sensorimotor embodiment grounding devices. As such, it is one of the clearest candidates for conceptualization using a cross-domain strategy. Metaphor theory has helped uncover some of the ways in which morality is understood across many cultures, looking at recurrent linguistic patterns (Lakoff and Johnson 1980, Lakoff 1996). Thus, we find a number of sensorimotor domains connected to the domain of MORALITY. For example, we use the concrete domain of CLEANLINESS: if something is clean, then it is moral, and something dirty is something immoral. So, we speak of a dirty trick or a clean conscience. The existence of this metaphor at a mental level, that is, the fact that there is a connection between both domains that goes beyond language, has been shown experimentally, via the so-called "Macbeth effect". Zhong and Liljenquist (2006) conducted a number of experiments in which they showed these connections through nonlinguistic tasks. In their experiments, the physical cleansing of participants had an effect on their feeling of guilt due to immoral actions; it also softened their judgments of other persons' misdeeds. Conversely, associations with unethical behavior were shown to increase the desire of physical cleansing. This connection between physical cleanliness and morality has been replicated experimentally by many other scholars (e.g., Schnall et al. 2008, Lee and Schwartz 2010). Needless to say, this is not the only metaphor used for MORALITY: MORALITY is also conceptualized with the help of the domain of RECTITUDE. If something is moral, it is straight, and something immoral is "crooked" or "bent" (cf. he is a crooked businessman, I have always been straight with you). Other additional metaphors are MORALITY AS VERTICALITY (cf. an upstanding citizen, a low trick, high morals), MORALITY AS BOUNDS (cf. going astray,

\footnotetext{
2 This connection, which is posited by supporters of "natural law", is not as straightforward as could be initially thought. Defenders of "positive law" opt instead for a separation of legal codes from natural law. However, this is a more technical argument, and the connections between law and morality seem clear enough to lay people.
} 
stepping out of or transgressing bounds, deviating from the path) or MORALITY AS PURITY (cf. pure/impure thoughts), to name a few.

But probably the single most pervasive metaphor for morality found in colloquial language relates it to ACCOUNTANCY. If you do something good for someone, that person "owes" you, or is "indebted" to you. Equally, if you carry out an immoral action against someone, that someone can "make you pay" for it. This can be done with an action of the same negative "value" (an action that receives the name of "revenge"). Alternatively, you can carry out a deed of the same "value" but negative polarity, which can serve as "compensation" and set the record "even".

The idea behind all these expressions is that our actions are given a specific value, positive when they are good actions and negative when they are bad actions, and people keep a record of accountancy. This may seem a rather "materialistic" way of dealing with moral actions, but it is in fact the most pervasive metaphor we have for dealing with morality. The translation of the moral value of a given action to a more concrete type of value has been applied in our legal systems since the dawn of time. All societies have striven to find some type of equivalence between these two poles: depending on the category of the deed, there is a "price" to be paid. Now, different societies in different moments in time have opted for different currencies of such a price. Sometimes that currency can be cows (as in many African cultures), pigs, or other types of cattle; it can also be money or a valuable object (e.g. a given possession); it can be years of prison, or even the offender's life.

For example, the well-known Hammurabi code (around 1772 B.C.) tended to use physical harm ('an eye for an eye') in exchange for moral misconduct, and listed a number of actions, which had to be paid for with a life:

- Law \#3. If a man has borne false witness in a trial, or has not established the statement that he has made, if that case be a capital trial, that man shall be put to death.

- Law \#15. If any one take a male or female slave of the court, or a male or female slave of a freed man, outside the city gates, he shall be put to death.

- Law \#22. If any one is committing a robbery and is caught, then he shall be put to death.

Other ancient codes tended to use money as compensation; for example, these are some laws in the Ur-nammu code (2100-2050 B.C.):

- If a man commits a kidnapping, he is to be imprisoned and pay 15 shekels of silver.

- If a man divorces his first-time wife, he shall pay her one mina of silver. If it is a (former) widow whom he divorces, he shall pay her half a mina of silver. 
Similar arrangements are found in the Lipit-Ishtar code (1870 B.C.):

- (Art. 9) If a man entered the orchard of another man and was seized there for stealing, he shall pay ten shekels of silver

- (Art. 36) If a man rented an ox and broke its horn, he shall pay one-fourth its price

These two currencies (physical harm, including death, and monetary compensation) have remained among the most popular options in Western societies. In the early Germanic societies, they were applied in the form of Weregild (which established a concrete price for every human being and for every piece of property), and blood revenge. Thus, if for example someone was killed, the guilty person would have to pay a "weregild" to the victim's family, or otherwise blood revenge would be taken.

Nowadays, the currency we have agreed upon is prison time: each moral action (after it has been carefully categorized; see section 3) is "valid" for a number of years. Thus, a person guilty of "arson" may have to go to prison for 5 years, somebody guilty of "murder" may have to go to prison for 30-50 years (depending on the legal system applied), etc. Each action is thus put in a given category (e.g., first-degree murder, second-degree, third-degree, etc.), and each category is associated with a given value in terms of years of prison. The process of categorization is in this way crucial and completely central to the whole enterprise; this is what we examine in our next Section 3.

\section{Prototype CATEgorization}

In the 1970s, psychologist Eleanor Rosch conducted a number of elegant experiments that establish a new perspective on how people form categories (Rosch 1973, 1975, 1978). In the classic, Aristotelian approach, categorization was concerned with finding the necessary and sufficient features common for all members of a given category. The application of this list of features produced, as a result, a number of sharply defined categories. Belonging to a given category was thus established binarily (by inclusion or exclusion) and all members of the categories had exactly the same status. In the new approach introduced by Rosch and her colleagues, the categorization of a given element is carried out with respect to the most typical and best exemplar of the category; the tighter the fit, the most centrally an element is placed within the category. The system also allows for peripheral categorization, in which elements which diverge to a certain extent from the prototype can still be included within the category, in a less central position. There is no set of necessary and sufficient features that can be applied to all members of the category, which are related by "family resemblances" (Wittgenstein 1957). Prototypical members share a higher number of features with the rest, while peripheral members can share 
only some features, but not others. An essential feature of this type of categorization is that categories are not "binary": belonging to a given category can be a matter of degree. Categories are thus fuzzy, and can merge into one another. This fact has a great relevance for law practice, because the expectations now are that only very prototypical actions will be easily categorized, and there exists the possibility of finding intermediate cases, which can be accommodated by two partially overlapping categories.

Another important and related fact is that categories are not "out there" in nature, but are created by conceptualizers (Lakoff 1987). Thus, a category is a mental construct that helps us organize our behavior, and that justifies its existence by its usefulness, more than by its "truth value". We can predict how an element will behave depending on how we categorize it, since one of the main purposes of categorization is to transfer information from one exemplar to another. If based on visual information alone we are able to categorize one specific piece of fruit within the category "apple", the information that we may have about other members of the category (e.g. that they are edible) becomes available for that specific exemplar as well. Different animals categorize the world depending on their specific needs; different cultures do the same. The non-objectivist view of the world that is associated with prototypical categorization is again of great importance to legal practice, since it is essential to find the right epistemic framework in which legal decisions take place.

Finally, categorization, and, specifically, linguistic categorization, is not an innocent or neutral act. Work in cognitive psychology has proven that using a linguistic label for an element changes its representation in our minds. It is an invitation to focus on the similarities with the other members of the category, on the one hand, and on the differences with non-members of the category, on the other. For example, in a series of experiments, Lupyan (2008a) asked participants to examine a number of familiar objects (e.g., chairs, lamps and tables). Sometimes participants had to classify the objects using a "preference" rule (by pushing a "like" or a "don't like" button); sometimes they had to classify them using a linguistic label (by pushing a "chair" or a "table" button). In a second phase of the experiment, they were shown again a number of objects; these objects could be either the same they had previously seen or slight variations of them (e.g., a chair with a slightly different height, color or material). This time, they had to press the buttons "new" or "old" to indicate whether they had already seen them or not. In a very consistent way, people remembered more accurately the elements they had categorized using the "like/don't like" rule, compared to those they had categorized using a linguistic label. Categorizing an element with an explicit linguistic label thus brought its mental representation closer to the prototype, and made people focus on the similarities to the prototype. Aspects that are deemed less relevant for the categorization process (i.e., within-category differences), receive less attention (and are thus more easily forgotten). This explains why it is such a crucial 
matter to discuss each of the individual features that can associate a given action to a legal prototype. When a lawyer succeeds in establishing a connection between even just one single category-related feature and the action being categorized, other aspects of the case that make it more similar to this legal category become highlighted. This "gravitational pull" of the prototypical center, so to speak, can alter the perception of the whole action, which is in this way dynamically shifted to accommodate it to the prototype, in a sort of "winner-takes-all" effect.

Due to the inherently multifaceted nature of most elements, categorization can be a highly problematic issue (Geeraerts 1989). In the case of moral actions, the process is further complicated by one very specific and critical parameter: the intentionality of the wrongdoer. In most cases, in order to determine the morality of an action and categorize it accordingly, we need to "guess" what the intentions of the accused person were. What was the purpose of the person carrying out the offending action? What was on his/her mind? Answering this requires deep theory-of-mind capabilities, by which we infer the mental states of an actor (e.g., his/her beliefs and intentions). ${ }^{3}$ This is in all probability the single most controversial issue in moral categorization, a problem that has been acknowledged in all moral and legal codes. For example, while the generic Hebrew word for any kind of sin is aveira ("transgression"), Judaism describes three levels of sin:

1. Pesha - an "intentional sin"; an action committed in deliberate defiance of God

2. Avon - a "sin of lust or uncontrollable emotion, committed against one's will and is not in line with one's true inner desires". It is a sin done knowingly, but not done to defy God

3. Chet - an "unintentional sin", something that is done but without the intention to $\sin$

The categories we find in most legal systems nowadays do in fact depend on this thorny issue: the intentionality of the agent. This is what underlies, for example, the distinction between the two main cases in which a person causes the death of another: manslaughter vs. murder. Thus, an action is categorized as "involuntary manslaughter" when the agent has carried out an (illegal) act that was likely to harm another person, and indeed caused someone to die, but such

\footnotetext{
${ }^{3}$ Cognitive science has made some progress into this problem. Apparently, the Temporoparietal Junction, an area of the bran where the temporal and parietal lobes meet and which is involved in the association of emotions to events or individuals, is crucial in moral reasoning. Some experiments have shown that disruption of the neural activity in this area using the technique known as TMS (Transcranial Magnetic Stimulation), (Young et al., 2010) affects our capacity to use mental states in moral judgment.
} 
a consequence of the action was neither foreseen nor intended by the agent. Dropping a brick from a bridge, for example, could be done with no specific intention of killing, but if it the action results in the death of someone, the agent is guilty of extreme recklessness (in English law, this would receive the name of "constructive manslaughter"). In contrast, the category "voluntary manslaughter" is applied to cases in which a person kills another one with malice and intentionality (i.e., the action is carried out with the intention of causing harm or even killing), but the action itself had not been previously planned. Such would be the case of someone killing a person in a sudden fight (this is sometimes called "chance-medley" in English law). Extreme provocation is another of the attenuating factors that can push the classification of an act of killing from murder to manslaughter. Finally, there is the category of "murder", which is the unlawful ${ }^{4}$ killing of a person. In this case, the person intends to kill the victim and carries out a deliberate and premeditated action with the result of death. There are an additional number of circumstances that can displace the case within the radial prototypical space of the category, bringing it towards the center or the periphery, and thus making the case more or less serious. These are known as "mitigating" or "aggravating" circumstances. Thus, depending on the different legal systems, mitigating circumstances can include insanity, postpartum depression or diminished capacity, among other factors. On the other hand, aggravating circumstances can be features such as exceptional brutality or cruelty, or sometimes depend on the type of victim involved (e.g., the murder of a pregnant woman, of a police officer, a judge, a fireman, or of the witness to a crime can all be aggravating circumstances).

\section{THE ROLE OF LANGUAGE: FRAMING SYSTEMS}

As we have mentioned previously, categorization is not an easy business. Humans have the capacity to focus on any of the perceived attributes or components of an element depending on contextual needs (Labov 1973). This means that depending on the attribute we focus on, we can group a given object along with an indefinite number of other different objects with which it shares the specific characteristic we have selected. To give but a trivial example, an "apple" can be grouped within the category of "fruit" (along with other items such as bananas and pears), but it can also be grouped with "items that can be bought in a supermarket" (along with chicken, milk, coffee and all sorts of domestic cleaning products); it can also be grouped with "healthy food" (along with whole-wheat and omega-3-fish), with "round objects" (along with tennis balls or eggs), with "red objects" (if the apple is red), or in a possibly openended list of ad-hoc categories (Barsalou 1983). Each of these categorizations

\footnotetext{
${ }^{4}$ There are a number of cases in which a man can legally kill another one (again, as always, depending on the different legal systems), such as soldiers in wars, self-defense cases, or an executioner who carries out the orders of the state.
} 
imposes a different viewpoint on the element itself, highlighting some facets while leaving some others in the background, out of the attention of the cognizer. As mentioned previously, categorizing maximizes both withincategory similarities and between-category differences.

Now, linguistic descriptions impose specific viewpoints of the scene described in ways that go beyond the mere choice between one lexical category or another for a given element. Think of a scene in which a boy breaks a window by throwing a ball at it. This event can be coded linguistically in different ways, and each of them imposes a different perspective on the scene. Thus, "the boy broke the window" brings the agent, the boy, into full focus. We can alternatively say, "a ball broke the window", thus hiding the role of the agent. Or we can even choose to focus solely on the result of the event by saying "the window broke". These would be examples of "windowing of attention" (Talmy 2000), by which language is assimilated to the "focus" of a spotlight that selects parts of a scene, leaving others in the dark.

Fausey and Boroditsky (2010) conducted a number of experiments that confirmed the all-important role of linguistic framing in the attribution of blame and financial liability. For example, participants would read a story about an individual ('Mrs. Smith'), who became accidentally involved in a restaurant fire. There were two versions of the story, which were identical except for the verbal frame used in the description of the accidental event: one used a transitive (and thus, agentive) frame: e.g., Mrs. Smith flopped the napkin on the centerpiece candle. The other version used an intransitive (and thus, non-agentive) verbal frame: e.g., her napkin flopped on the centerpiece candle. Participants who had been given the transitive version tended to attribute more blame to Mrs. Smith and also thought that she should be required to pay more money to the restaurant for damages. In another experiment in the series, participants watched a video: the well-known and controversial incident which took place during the 2004 US Super Bowl finals, in which Justin Timberlake ripped the costume of Janet Jackson, exposing her bare breast. Participants were provided again with a verbal description that contained an agentive version of the incident (he ripped the costume) or a non-agentive one (the costume ripped). Though all participants watched the same video, participants who heard the transitive version tended to attribute more blame on Justin Timberlake and less on chance than those given the intransitive version. They also tended to think that the financial responsibility of Timberlake was higher. This experiment shows how the way in which we construe an event, and specifically, the attribution of blame, can be greatly influenced by the linguistic choices we make for its description, even in the case of eyewitnesses.

Filipovic (2013a) is another study that compares witness memory in speakers of different languages. Her study compares the expression of causal intentionality in English and Spanish. In English, a sentence such as "she dropped the keys" is ambiguous with respect to intentionality. In Spanish, the expression 
of intentional vs. non-intentional actions is quite clear, since non-intentional actions are expressed with a different construction ('se le cayeron las llaves'). In her experiments, she showed how this language-guided habit of distinguishing intentional from non-intentional readings favorably affected the witness memory of Spanish speakers as compared to English speakers. The lack of pressure of English speakers to express in a linguistically explicit way the causation component made them pay less attention to it and accordingly weakened their memory of it. Other researchers have also found differences in eyewitness memory of intentional actions (e.g., English vs. Japanese speakers, Fausey et al. 2010; or English vs. Spanish speakers, Fausey and Boroditsky 2011). Filipovic (2013b) also focuses on a number of typological language contrasts, specifically, the expression of motion and of causation, showing their crucial importance for "witness interviewing, interpreting, translating, remembering, and forming judgment in legally relevant contexts".

All these works issue a very strict warning about the type of translations which are used in court proceedings; Filipovic (2007) reports a case in which a Spanish-speaking individual in a Northern California court described an event with a non-agentive frame ('se me cayó' - 'it dropped - from me') which was erroneously translated in court using a agentive English equivalent ('I dropped her'). As has been shown here, the attribution of blame is greatly affected by the type of linguistic framing used, and all subjects involved in legal procedures should be well aware of this.

In all the cases described above, the framing effect is brought about by means of focusing on certain elements within a frame, putting others in the background (Talmy's windowing of attention). But this is not the only possible framing strategy: in CL words are understood with respect to an underlying frame (Fillmore 1982). Frames are complex entities, typically containing a number of different elements; these frame elements can be activated by different words, therefore highlighting a selected portion of the frame structure and imposing a given perspective. When we use one word, the other elements in its frame are also activated. For example, in a commercial transaction frame, a "salesperson" is the person employed by a business to sell its merchandise to customers. Thus, using the single word "salesperson" will automatically activate all these related concepts. The word "pusher" (as in "drug-pusher") makes reference to a similar event (a commercial transaction), but the frame elements are now different: the thing that is sold/bought is "drug", the transaction does not take place typically in a shop, and the customers are substance-abusers. Quite often, near-synonyms make references to very different frames, and changing one word even for a very similar one, can have a dramatic effect (in the famous words of Dwight Bolinger, language is a loaded weapon). Coulson (2011) has studied the phenomenon known as "frameshifting": classifying a child as a "cry-baby" or as a "highly-sensitive child" alters dramatically the type of response that is appropriate for each case. If 
somebody is described as "thrifty", we apply by default the reasons this person may have for not spending money (probably, frugality or moderation); if the description applied to the person is "stingy", the reasons for not spending money would be assumed to be different (probably, greed or selfishness).

Cognitive linguistics has studied how the language we use is inevitably associated with a given framing and how this can be put to use in persuasive functions (Bizer and Petty 2005, Fausey and Matlock 2011, Goffman 1974, Lakoff 1996b, 2004, 2008). This is why, for example, American conservative politicians are advised not to use the phrase "drilling for oil", and opt instead for the more neutral and positively connoted "exploring for energy". Even the most innocent of words "drags" with it a number of conjoined elements, taken from its background frame, which can color the word with connotations and contribute to it a number of default assumptions which are unconsciously present. As Todd Gitlin put it: "Frames are principles of selection, emphasis and presentation composed of little tacit theories about what exists, what happens, and what matters" (Gitlin 1980: 6). The use of framing in rhetoric is thus of the utmost importance for legal practitioners, i.e., for those who hope to present a given event in a specific light so that certain interpretations, inferences and explanatory schemes are encouraged at the expense of competing ones.

\section{FRAMING-BY-METAPHOR}

Abstract concepts, by definition, are not directly grounded in our embodied experience (i.e., we do not see them, touch them, smell them, etc.). Conceptual Metaphor Theory proposes a mechanism by which the embodied grounding of concrete, sensorimotor domains (Barsalou 2008) is analogically extended to abstract concepts, which become in this way more consistently structured and better understood. This transfer of inferences from a concrete domain to an abstract domain allows a type of reasoning that would not be possible without this connection. Lakoff and his colleagues have in fact proposed that all abstract concepts are based on metaphor (Lakoff and Johnson 1980, 1999).

Metaphors are also framing devices: they invite the hearer to form a conceptualization from a given perspective. ${ }^{5}$ Lawyers have been aware of this for a long time; in this sense, metaphors have always been used for rhetorical purposes. For example, classical scholars such as Quintilian or Cicero already mentioned them in their treatises on persuasive mechanisms. Metaphors often bring emotional overtones and forceful arguments, justifying their usefulness in

\footnotetext{
5 Though this section is going to discuss the role of conceptual metaphor in argumentative settings, it must be mentioned that this is not "the only game in town" within CL. Conceptual Integration Theory, also known as Blending Theory (Fauconnier and Turner 2008), a more complex and dynamic cross-domain mapping model, has also been applied in these contexts. See for example, Pascual (2006) or Yao and Pascual (in prep) for studies of blending used as an argumentative strategy in legal settings.
} 
legal practice. Recent studies have been able to connect this classic practice to the theoretical insights of cognitive linguistics. Thus, metaphors have been discussed in connection with contract law (Lipshaw 2011) and legal discourse (Chiu and Chiang 2011); they have also been proposed as the basis for models of legal theory (Makela 2011). Another interesting study is Hibbitts (1994), who offered a discussion of the change from visual to aural metaphors in American legal practice. On the website "www.thecompletelawyer.com", we are told explicitly that "lawyers can use metaphoric re-framing to shift readers' understanding of their arguments and smooth the way toward conclusions favorable to their clients". The same argument is found in Linda Berger's work "What is the Sound of a Corporation Speaking? How the Cognitive Theory of Metaphor Can Help Lawyers Shape the Law":

The lawyer who wants to influence judicial perceptions and decisions can draw on the insights of cognitive research. A new metaphor can make the target experience understandable in a different light by highlighting some aspects of the target and suppressing others. The new metaphor may entail very specific aspects of the source concept, and in this way, it can give the target a new meaning, sanctioning different actions, justifying revised inferences, and leading to different goals and results (Berger 2004: 207).

A recent study by Thibodeau and Boroditsky (2011) has been able to test experimentally the influence of metaphor on reasoning. They examined how different metaphors affected the judgments of subjects about crime and about how this problem should be addressed by society. In their experiment, they gave participants two texts describing the same situation: an increase in the crime rate of the imaginary city of Addison. The texts contained the same information, but made use of two different metaphors to describe crime. So, while Text A used the metaphor CRIME IS A DISEASE (describing crime as a "virus infecting the city" and "plaguing the neighborhoods"), Text B used the metaphor CRIME IS A BEAST (describing crime as a "wild beast preying on the city" and "lurking in neighborhoods"). After reading one of the versions of this text, participants had to propose a number of solutions. The solutions proposed were found to be influenced by the metaphor used in the text. So, participants who had read the text with the crime-as-disease metaphor tended to favor "social reform-like" solutions (e.g. improving social programs, providing better health-care, etc.), while those who read the text that used the crime-as-beast metaphor tended to favor "enforcement-like" solutions (e.g., harsher prison penalties, building more jails, etc.). In this way, these results were able to demonstrate that metaphor influences people's reasoning in a way similar to frames: metaphors were able to provide a structured framework for understanding the abstract notion of crime. Metaphors also prompted a biased perspective of the issue at hand (building a virus-like or a beast-like mental representation of crime) and motivated a number of consistent inferences. 
Incidentally, subjects reported not being aware of the type of metaphor that had been used, which in one of the experiments was activated with just a single word ('crime'/'beast').

\section{CONCLUSION}

CL has developed a number of strategies for the analysis of language that can be usefully applied to other cognitive processes as well. In this paper, we have reviewed some of these basic strategies and have examined how they can be applied to the domain of legal practice. We have seen how the domain of morality itself, which serves as a backdrop for legal systems all over the world, is structured metaphorically. The way we organize our moral (and legal) systems is thus a perfect example of one of those "metaphors we live by". Our current legal systems can be described as an implementation of the metaphor MORALITY AS ACCOUNTANCY. Politicians use this metaphor when they discuss different laws, negotiate the different "prices" that our actions may have, and adjust in complex ways debts to be paid to society. The strategies that lawyers use to influence the decision of the judge (or the jury) and bias a given case towards one category or another, shifting the case towards the prototype or the periphery of a given category, are in fact mechanisms that have been studied by cognitive linguistics, under the labels of windowing of attention, linguistic framing and framing-by-metaphor. The psychological reality of these mechanisms has been solidly established by abundant empirical research, as has been their effect on memory, attention, reasoning and inferencing. As has been shown, cognitive linguistics can thus help to explain matters central to law practice, including such specific factors as differences in eyewitness memory, or the parameters that intervene in the attribution of blame and guilt.

Taken all together, these results should be of great interest to all participants involved in the legal process. A better understanding of how we organize our moral world and a more precise view of the psychological mechanisms involved in our current legal practices can only add to our own benefit and to a better application of our laws.

\section{REFERENCES}

BAIRD, J.A. and ASTINGTON, J.W. (2004), "The role of mental state understanding in the development of moral cognition and moral action", New Directions for Child and Adolescent Development, 103: 37-49.

BARSALOU, L.W. (1983), “Ad-hoc categories”, Memory and Cognition, 11: 211-227.

BARSALOU, L.W. (2008), “Grounded cognition”, Annual Review of Psychology, 59(1), 617645.

BERGER, L. (2004), "What is the Sound of a Corporation Speaking? How the Cognitive Theory of Metaphor Can Help Lawyers Shape the Law", 2 J. ALWD 169. 
BIZER, G.Y., and PETTY, R.E. (2005), "How we conceptualize our attitudes matters: The effects of valence framing on the resistance of political attitudes", Political Psychology, 26: 553-568.

BROSNAN, S.F., and DE WAAL, F.B.M. (2003), "Monkeys reject unequal pay", Nature, 425, 297-299.

CHIU, S. and CHIANG, W. (2011), "FIGHT Metaphors in Legal Discourse: What Is Unsaid in the Story?", Language and Linguistics, 12.4: 877-915, 2011.

COUlson, S. (2001), Semantic leaps: Frame shifting and conceptual blending in meaning construction, New York, Cambridge University Press.

De WAAL, F. (2006), Primates and Philosophers: How Morality Evolved, Princeton University Press.

FAUCONNIER, G. and TURNer, M. (2008), The way we think: Conceptual blending and the mind's hidden complexities, New York, Basic Books.

FAUSEY, C., and BORODITSKY, L. (2010), "Subtle linguistic cues influence perceived blame and financial liability", Psychonomic Bulletin \& Review, 17 (5), 644-650. Available at: $<10.3758 /$ PBR.17.5.644>.

FAUSEY, C. and BORODITSKY, L. (2011), “Who dunnit? Cross-linguistic differences in eyewitness memory", Psychonomic Bulletin \& Review: Volume 18, Issue 1, Pages 150-157. Available at: $<10.3758 / \mathrm{s} 13423-010-0021-5>$.

FAUSEY, C., LONG, B., INAMORI, A., and BORODITSKY, L. (2010), “Constructing agency: the role of language", Frontiers in Psychology. Available at: $<10.3389 /$ fpsyg.2010.00162>.

FAusey, C. M., and MATLOCK, T. (2011), “Can grammar win elections?", Political Psychology, 32: 563-574.

FILIPOVIC, L. (2007), “Language as a witness: Insights from cognitive linguistics", International Journal of Speech, Language \& the Law, 14, 245-267.

FILIPOVIC, L. (2013a), “Constructing causation in language and memory: Implications for access to justice in multilingual interactions", International Journal of Speech, Language and the Law, 20 (1), 1-19.

FILIPOVIC, L. (2013b), “The role of language in legal contexts: A forensic cross-linguistic viewpoint", International Journal of Law and Language: Current Legal Issues, 328-343 UEA Repository (Chapter).

FILlMORE, CH. (1982), “Frame semantics. In Linguistic Society of Korea” (Ed.) (1982), Linguistics in the morning calm (pp. 111-138), Seoul, Hanshin.

FILLMORE, CH. and B. ATKINS (1992), "Toward a frame-based lexicon: The semantics of RISK and its neighbors", in Frames, fields and contrasts, A. Lehrer, and E. Kittay (Eds.), (pp. 75-102), Hillsdale, N.J., Lawrence Erlbaum.

GeERAERTS, D. (1989), "Introduction: Prospects and Problems of Prototype Theory", Linguistics 27: 587-612.

GiTlin, T. (1980), The Whole World Is Watching: Mass Media in the Making and Unmaking of the New Left, Berkeley, CA, Los Angeles, CA \& London, U.K., University of California Press.

GOFFMAN, E. (1974), Frame Analysis: An Essay on the Organization of Experience, New York, NY et al., Harper \& Row.

HAUSER, M. (2006), Moral minds: How nature designed our universal sense of right and wrong, New York, Harper Collins. 
HiBBITS, BERNARD I. (1994), "Making Sense of Metaphors: Visuality, Aurality, and the Reconfiguration of American Legal Discourse", 16 Cardozo Law Review 245.

LABOV, W. (1973), "The boundaries of words and their meanings", in New Ways of Analysing Variation in English, C.-J.N. Bailey and R. W. Shuy (eds.), Washington, Georgetown University Press.

LAKOFF, G. (1987), Women, Fire and Dangerous Things: what categories reveal about the human mind, Chicago, Chicago University Press.

LAKOFF, G. (1996), "The Metaphor System For Morality", in Conceptual Structure, Discourse, and Language, Goldberg, A. (ed.), Cambridge University Press.

LAKOFF, G. (1996), Moral Politics: How Liberals and Conservatives Think, Chicago, University of Chicago Press.

LAKOFF, G. (2004), Don't Think of an Elephant: Know Your Values and Frame the Debate, Chelsea Green Publishing.

LAKOFF, G. (2008), The Political Mind: Why You Can't Understand 21st-century American Politics with an 18th-Century Brain, New York, NY, Penguin Press.

LAKOFF, G. (2013), "Metaphor and War: The Metaphor System Used to Justify War in the Gulf", Cognitive Semiotics, Volume 4, Issue 2, Pages 5-19, ISSN (Online) 22352066, ISSN (Print).

LAKOFF, G. and JOHNSON, M. (1980), Metaphors we live by, Chicago, University of Chicago Press.

LAKOFF, G. and JOHnSON, M. (1999), Philosophy in the flesh, New York, Basic Books.

LEe, S. and SchWARZ, N. (2010), "Washing Away Postdecisional Dissonance", Science, 2010; 328 (5979): 709. Available at: $<10.1126 /$ science.1186799>.

LIPSHAW, J.M. (2011), "Metaphor, Models, and Meaning in Contract Law" (June 23, 2011), 116 Penn. St. L. Rev. 987 (2012); Suffolk University Law School Research Paper No. 11-04. Available at <http://ssrn.com/abstract $=1761575>$ or $<$ http://dx.doi.org/10.2139/ssrn.1761575>.

LuPyAN, G. (2008a), “The Conceptual Grouping Effect: Categories Matter (and named categories matter more)", Cognition, 108: 566-577.

LuPYAN, G. (2008b), "From Chair To "Chair:" A Representational Shift Account Of Object Labeling Effects On Memory", Journal of Experimental Psychology: General 137(2): 348-369.

MAKELA, T. (2011), "Metaphors and Models in Legal theory", Les Cahiers de Droit, vol. 52, nos 3-4, septembre-décembre 2011, pp. 397-415.

PASCUAL, E. (2006), "Questions in legal monologues: Fictive interaction as argumentative strategy in a murder trial", Text $\mathcal{E}$ Talk 26(3): 383-402.

ROSCH, E. (1973), "On the internal structure of perceptual and semantic categories", in Cognitive Development and the Acquisition of Language, T. E. Moore (ed.), 111-44, New York, Academic Press.

ROSCH, E. (1975), "Cognitive representations of semantic categories", Journal of Experimental Psychology: General, 104: 192-233.

Rosch, E. (1978), "Principles of categorization", in Cognition and Categorization, E. Rosch and Lloyd, B.B. (eds.), Hillsdale, Lawrence Erlbaum, 27-48.

SCHNALL, S., BENTON, J. and HARVEY, S. (2008), "With a clean conscience: Cleanliness reduces the severity of moral judgments", Psychological Science, 19, 1219-1222

TALMY, L. (2000), Toward a cognitive semantics, Cambridge, Mass., The MIT Press. 
ThiBODEAU, P.H. and BORODITSKY, L. (2011), "Metaphors We Think With: The Role of Metaphor in Reasoning", PLoS ONE 6(2): e16782. Available at: <10.1371/ journal.pone.0016782>.

THIBODEAU, P.H. and BORODITSKY, L. (2013), “Natural Language Metaphors Covertly Influence Reasoning", PLoS ONE 8(1): e52961. Available at: <http://wwwpsych.stanford.edu/ lera/papers/crime-metaphors.pdf $>$.

WitTgensteIn, L. (1957), Philosophical Investigations, Translated by G. E. M. Anscombe, Oxford, Basil Blackwell.

YAO, L. and PASCUAL, E. (In prep.), "Screaming evidence and emotional lawyers: Fictive interaction strategies in Eastern and Western criminal cases", in E. Pascual and Sandler, S. (eds.)

Young, L., CAMPROdON, J.A., HAuser, M., PAscual-LeOne, A., and SAXe, R. (2010) "Disruption of the right temporoparietal junction with transcranial magnetic stimulation reduces the role of beliefs in moral judgments", Proceedings of the National Academy of Sciences USA 107: 6753-6758.

ZHONG, C. B., and LILJENQUist, K (2006) "Washing Away Your Sins: Threatened Morality and Physical Cleansing", Science 313, September 8; 2006; 1451-1452. 